\title{
PERSPEKTIF MULTIKULTURAL PADA PENDIDIKAN AGAMA ISLAM DI MADRASAH ALIYAH
}

\author{
Rohmat, Zamroni, Achmad Dardiri
}

Sekolah Tinggi Agama Islam Negeri Purwokerto, Universitas Negeri Yogyakarta zein_rohmat@yahoo.co.id, zamronihardjowirono@yahoo.com, achmaddardiri@uny.ac.id

\begin{abstract}
Abstrak
Penelitian ini bertujuan menemukan makna multikultural menurut guru Pendidikan Agama Islam Madrasah Aliyah (MA) MINAT Cilacap. Penelitian ini merupakan penelitian kualitatif-naturalistik. Penelitian dilakukan di MA MINAT Cilacap. Waktu penelitian intensif di lapangan dilakukan Januari 2012- Februari 2014. Subjek penelitian dipilih dari para praktisi pendidikan di MA MINAT Cilacap dan guru Pendidikan Agama Islam yang terdiri atas guru mata pelajaran Alquran/hadis, Akidah/akhlak, Fiqih dan Sejarah Kebudayaan Islam. Teknik pengumpulan data adalah observasi, wawancara, dan dokumentasi. Teknik analisis data dilakukan dengan teknik analisis induktif dengan beberapa langkah utama yaitu pengumpulan data, reduksi data, penyajian data, dan kesimpulan atau verifikasi. Hasil penelitian menunjuukan makna multikultural menurut guru Pendidikan Agama Islam MA MINAT Cilacap yaitu: makna persamaan hak, persaudaraan dan toleransi. Hal tersebut tidak lepas dari pengaruh yang dikembangkan institusi MA MINAT Cilacap yang mengembangkan konsep tawazun (keseimbangan antara dunia dan akhirat) dan mengedepankan tasamuh (toleransi) yang membawa konsep yang baik terhadap pendidikan multikultural. Guru Pendidikan Agama Islam MA MINAT Cilacap memberi makna multikultural antara lain tentang persamaan hak yang harus diberikan lembaga pendidikan sebagai institusi sebagai tempat untuk melakukan pemberdayaan siswa. Persamaan hak menjadi pondasi dasar dalam meminimalisasi konflik yang berkembang dalam masyarakat. Pemberdayaan siswa MA MINAT Cilacap pada sikap persamaan hak memberikan nilai positif pada pembentukan perilaku yang lebih menerima perbedaan.
\end{abstract}

Kata kunci: pendidikan multikultural, pendidikan agama Islam, madrasah aliyah

\section{MULTICULTURAL MEANING REVIEW IN ISLAMIC EDUCATION AT MADRASAH ALIYAH}

Rohmat, Zamroni, Achmad Dardiri

Sekolah Tinggi Agama Islam Negeri Purwokerto, Universitas Negeri Yogyakarta zein_rohmat@yahoo.co.id, zamronihardjowirono@yahoo.com, achmaddardiri@uny.ac.id

\begin{abstract}
This study has purposed to find multicultural meaning in Islamic education teacher MA MINAT Cilacap. This research is natural-qualitative research. The research conducted in MA MINAT Cilacap. The intensive time in field research conducted in January 2012 - February 2014. The process of data analysis of multi-cultural studies on Islamic Education in MA MINAT Cilacap done several main steps: data collection, data reduction, data display, and conclusions or verification.The results of the study according to the meaning of multicultural Islamic education teacher MA MINAT Cilacap are: the meaning of equality,tolerance, brotherhood. It is not free from the influence in MA MINAT Cilacap developed the tawazun concept (the balance between the world and the Hereafter), and prioritize Tasamuh (tolerance) to bring a good concept of multicultural education. Islamic Education Teachers MA MINAT Cilacap multicultural give meaning among other things that should be given equal rights institution as the institution as a place for student empowerment. Equal rights became the basic foundation in minimizing conflicts that develop in society. Student in MA MINAT Cilacap empowerment on the attitude of equality gives a positive value on the formation behavior more accepting differences.
\end{abstract}

Keywords: multicultural education, Islamic education 


\section{PENDAHULUAN}

Fenomena yang menarik perhatian publik akhir-akhir ini semakin banyak, seperti maraknya tindak kekerasan berbasis agama atau yang mengatasnamakan gerakan agama. Tindakan penentangan terhadap negara menjadi perhatian serius. Selanjutnya muncul gerakan-gerakan separatis yang juga turut dipicu oleh perilaku penganut umat beragama. Fenomena tersebut menjadikan citra Indonesia sebagai negara dengan sebutan multikultural semakin tereduksi. Implikasi pemahanan atas normatif agama yang sepihak juga memunculkan semangat sektarian dan memiliki kecenderungan untuk membenarkan satu pemahaman tertentu atas tafsir agama dan menutup kebenaran atas tafsir agama yang dilakukan oleh kelompok lain.

Keluhuran nilai-nilai kearifan lokal juga menjadi faktor perekat kebangsaan, sebaliknya semangat menonjolkan nilai perbedaan dapat menumbuhkan separatisme (Lynch, 1986, p.70). Nilai gotong-royong sebagai salah satu kearifan lokal menjadi pilar kebersamaan dalam bernegara. Hal ini sesuai dengan kultur yang dimiliki oleh bangsa Indonesia sebagai bangsa yang memiliki keanekaragaman bahasa, budaya, dan suku bangsa.

Satu hal yang mutlak perlu dibangun Indonesia sebagai sebuah negara kepulauan dengan latar belakang masyarakat multikultural adalah penguatan nilai-nilai multikultural, sehingga ancaman disintegrasi bangsa semakin dapat diminimalisasi. Penguatan tehadap nilai-nilai kedaerahan dapat menjadikan faktor dominan dalam memperkokoh semangat nasionalisme dengan tetap menjunjung perbedaan dalam multikultural (Shihab, 2002, p.16). Nilai kemanusian dan keberagaman kultur juga sangat didukung oleh nilai-nilai agama.

Penafsiran agama yang benar dalam perspektif agama tetap mengedepankan nilainilai kemanusiaan dan perbedaan termasuk dalam multikultur. Norma agama tidak akan membunuh perbedaan yang ada, bahkan dalam Islam perbedaan menjadi rahmat. Islam datang sebagai agama rahmatan lil alamin (rahmat bagi alam). Pemaknaan dari pernyataan tersebut tidak hanya dalam konteks teologis tetapi dalam realitas kehidupan sosial budaya. Islam hadir untuk memakmurkan bumi dengan segala realitas perbedaan yang sangat kompleks. Kewajiban seorang muslim menjadi penebar perdamaian sebagimana yang telah diserukan dalam Q.S. al-Nisa: 114 yang artinya adalah "Tidak ada kebaikan pada kebanyakan bisikan-bisikan mereka, kecuali bisikan-bisikan dari orang yang menyuruh (manusia) memberi sedekah, atau berbuat makruf, atau mengadakan perdamaian di antara manusia. Dan barang siapa yang berbuat demikian karena mencari keridoan Allah, maka kelak Kami memberi kepadanya pahala yang besar".

Seruan damai dan harmonisasi dalam realitas kehidupan multikultural juga diperkuat dalam normatif Islam. Seorang muslim penting untuk melakukan relasi sosial tanpa tersekat oleh ragam budaya maupun keyakinan sebagaimana disebutkan oleh Alloh dalam Q.S. al-Hujurat: 13 yang artinya: "Hai manusia, sesungguhnya Kami menciptakan kamu dari seorang laki-laki dan seorang perempuan dan menjadikan kamu berbangsa-bangsa dan bersuku-suku supaya kamu saling kenalmengenal. Sesungguhnya orang yang paling mulia di antara kamu di sisi Allah ialah orang yang paling takwa di antara kamu. Sesungguhnya Allah Maha Mengetahui lagi Maha Mengenal".

Ayat tersebut memberikan implikasi bahwa perbedaan dalam Islam termasuk perbedaan dalam kultur menjadi satu keniscayaan dan tidak bisa dihindarkan. Islam datang sebagai agama yang dapat mengayomi semua golongan yang berbeda telah ada sejak Islam lahir. Islam mengajarkan kemaslahatan dan mengajarkan kesejahteraan untuk semua umat manusia, sehingga Islam menjadi sebuah agama yang bersifat demokratis atas semua perbedaan yang ada.

Islam datang dalam lingkungan yang multikultural. Nabi Muhammad Saw banyak bersentuhan dengan kultur Mekkah yang saat itu kental dengan agama dinamisme yang dipeluk oleh kaum Yahudi, sehingga Islam mengajak umat atas dasar kesadaran bukan atas paksaan dalam menganut Islam. Pengakuan yang tinggi atas perbedaan dalam Islam menjadikan penyebaran Islam didasarkan atas kebebasan bukan pada paksaan. Islam menjadi agama yang menjunjung tinggi nilai-nilai kemanusiaan di saat kultur mekkah yang penuh dominasi kekuasaan pada masa jahiliyah. Islam menjadi besar dengan ditopang 
kebebasan untuk memeluk Islam (Azra, 2002, p.15).

Justifikasi ketentuan di atas oleh Alloh disebutkan Q.S. al-Kafirun: 6 menyebutkan yang bermakna "bagimu agamamu dan bagiku agamaku". Dalam arti yang lebih luas Islam lahir sangat menjunjung kebebasan dalam beragama,menanamkan nilai-nilai kemanusiaan dan universalitas serta perbedaan, sehingga Islam sebagai sebuah agama sangat menjunjung nilai-nilai perbedaan dalam kehidupan multikultur. Satu fakta sejarah ketika Islam ditegakkan dalam pilar negara yang sangat mengakomodasi kepentingan semua elemen masyarakat yaitu ketika Nabi Muhammad saw berhasil memberlakukan Piagam Madinah yang merupakan sebuah aturan bernegara terdiri dari 47 klausul untuk melindungi dan menghormati kepentingan berbagai suku dan golongan antara orang Islam dan orang Yahudi serta merupakan perjanjian damai di antara kedua kaum (Tilaar, 2002, p.241).

Berdasarkan latar belakang tentang berbagai problem multikukultural, baik perbedaan bahasa, ras, budaya, agama, maupun problem intern umat Islam tentang berbagai perbedaan yang ada, perlu dilakukan eksplorasi terhadap internalisasi makna multikultural dari praktisi pendidikan karena pendidikan merupakan lembaga yang efektif untuk melakukan internalisasi nilai-nilai multikultural dalam diri siswa. Hal tersebut juga merupakan problem Pendidikan Agama Islam yang dihadapi pada Madrasah Aliyah Islamiyah Nahdlatutthullab Cilacap (selanjutnya disebut MA MINAT Cilacap). Pendidikan agama Islam berperspektif multikultural dilakukan untuk membentuk akhlak dan kesalihan sosial yang responsif terhadap kemajemukan, perbedaan bahasa dan kultur. Dengan demikian, output Pendidikan Agama Islam akan memiliki dua bentuk kesalihan tersebut yang pada akhirnya bentuk-bentuk deskriminasi antarpemahaman agama intern umat Islam dan kekerasan yang mengatasnamakan agama tidak akan terjadi. Perbedaan dan kondisis multikultural dihadapi oleh MA MINAT Cilacap.

Semula siswa MA MINAT Cilacap lebih didominasi oleh ikatan emosional dan ideologis kepesantrenan. Perspektif masyarakat mengalami perubahan tentang MA MINAT Cilacap bahwa kualitas madrasah men- jadi pertimbangan di samping ikatan emosional dan ideologis dalam menyekolahkan siswa. Kondisi tersebut juga dipengaruhi oleh adanya peningkatan orientasi dalam sistem manajemen kurikulum MA MINAT Cilacap. Pembaruan kurikulum MA MINAT Cilacap dilakukan dengan memadukan muatan lokal dan kompetensi kultural. Jika ditinjau dari rintisan awalnya yakni tahun 1952, MA MINAT Cilacap merupakan upaya pengembangan sistem di Pondok Pesantren Al Ihya Ulumuddin Cilacap. Model pembelajaran bandongan di pondok pesantren (ponpes) tersebut kemudian dikembangkan menjadi beberapa model, termasuk diantaranya sistem klasikal. Namun dalam perkembangan selanjutnyanya, madrasah ini kemudian mengadopsi kurikulum Kementrian Agama, dengan tetap mengembangkan kurikulum lokal yang bersifat eksklusif.

MA MINAT Cilacap memiliki keragaman siswa dari sisi pemahaman dan aliran mazhab yang ada dalam diri siswa, kultur, bahasa, dan etnis. Hal ini membawa konsekuensi bahwa latar belakang siswa sangat heterogen. Dengan demikian, MA MINAT Cilacap menghadapi problem multikultural yang perlu diselesaikan melalui proses Pendidikan Agama Islam.

Siswa MA MINAT Cilacap terdiri dari 80 persen berada di pondok-pondok pesantren yang berada di wilayah Kecamatan Kesugihan Cilacap. Asal daerah siswa MA MINAT beragam, yakni dari beberapa kabupaten di Jawa Tengah, sebagian lagi dari propinsi lain yakni Jawa Barat, Jawa Timur, Lampung, Medan, Kalimantan, Papua sehingga siswa MA MINAT Cilacap berasal dari berbagai kultur yang tinggal di asrama ponpes Al Ihya Ulumuddin Kesugihan Cilacap. Siswa yang berasal dari luar Jawa sekitar $30 \%$. Komposisi latar belakang siswa yang beragam membawa pola pergaulan siswa turut terbentuk dari keragaman yang dimiliki. Pola pemahaman aliran-aliran dalam Islam, amaliyah ibadah, serta bentuk-bentuk khilafiyah dalam ibadah menjadi beragam. Hal ini sangat dibutuhkan untuk pendidikan yang dapat menghargai keragaman.

Internalisasi nilai-nilai multikultural menjadi sangat nampak di MA MINAT Cilacap menyatu dengan komunitas pesantren Al Ihya Ulumudin yang melakukan kajian kitab-kitab salaf dan memadukan dengan 
model pesantren modern. Dari berbagai hal di atas MA MINAT Cilacap menjadi salah satu madrasah yang menjadi pionir tentang pendidikan berperspktif multikultural. Hal ini juga disebabkan oleh kondisi madrasah yang multikutur yaitu dengan adanya siswa yang berasal dari luar daerah.

Fenomena tersebut akan membawa konsekuensi pada Pendidikan Agama Islam di MA MINAT Cilacap dalam melakukan pendidikan berperspektif multikulutral terutama pada aspek guru Pendidikan Agama Islam ketika memaknai tentang multikultural. Aspek-aspek tersebut di atas dalam perpsektif MA MINAT Cilacap menjadi permasalahan penting untuk diteliti karena guru sebagai faktor dominan dalam pembentukan dan implementasi pendidikan multikultural di Madrasah.

Tinjuan multikultural dalam Pendidikan Agama Islam di MA MINAT Cilacap difokuskan pada aspek yang mendasar yaitu tentang pemaknaan multikultural menurut guru Pendidikan Agama Islam. Hal tersebut menjadi sangat urgen karena internalisasi nilai-nilai multikultural dalam diri siswa dimulai dari pemahaman tentang makna multikultural yang dimiliki oleh guru terlebih dahulu. Masalah yang dikaji dalam penelitian ini adalah: Bagaimanakah makna multikultural menurut guru Pendidikan Agama Islam di MA MINAT Cilacap.

Penelitian diupayakan untuk dapat memberi kontribusi yang bermakna terhadap perbaikan mutu Pendidikan Agama Islam yang memiliki tingkat toleransi tinggi terhadap keragaman perbedaan aliran intern umat Islam, ras, budaya, agama, dan keragaman berpikir, termasuk keragaman berpikir dalam bidang interpretasi norma agama Islam

Adap beberapa penelitian terkait dengan pendidikan multikultural di Indonesia yang masih berada dalam wacana dan pencarian dasar filosofis serta teknis implementasi, walaupun wacana pendidikan multikultural di Barat sudah menjadi kebijakan dalam pendidikan. Namun, beberapa paradigma pendidikan multikultural di Indonesia semestinya disesuaikan dengan kultur dan paradigma pendidikan yang berlaku di Indonesia.

Penelitian Marzuki dkk (2010, p.3) tentang Tipologi Perubahan dan Model Pendidikan Pesantren Salaf menemukan bentuk perubahan di pesantren salaf dan model pen- didikan multikultural didalamnya. Penelitian tersebut menggunakan metode deskriptif kualitatif dengan lokasi penelitian di Jawa yaitu Pesantren Al Qodir Cangkringan, Pesantren Dar Al-Tauhid Cirebon, Pesantren Roudlotul Thalibin Rembang, dan Pesantren Tebu Ireng Jombang. Kesimpulan penelitian adalah pertama, terjadi perubahan bentuk pendidikan di pesantren salaf yang tidak bisa lagi dikatakan bercorak salaf (tradisional) tetapi merupakan campuran antara tradisional dan modern, begitu juga dalam hal pemikiran kiai dan santrinya. Kedua, Islam yang dimiliki pesantren salaf adalah Islam inklusif, ramah, tidak kaku, moderat yakni Islam yang bernuasa perbedaan dan sarat dengan nilai-nilai multikultural.

Dari beberapa studi di atas, baik yang terkait dengan Pendidikan Agama Islam secara umum maupun yang secara khusus terkait dengan pesantren, tampak jelas bahwa studi yang memfokuskan kajiannya pada isuisu multikulturalisme dalam batas tertentu telah dilakukan oleh para peneliti. Namun demikian, studi terhadap pesantren yang secara spesifik memfokuskan pada model pengembangan kurikulum multikultural yang meliputi aspek perencanaan, implementasi, dan evaluasi kurikulum belum memperoleh perhatian dari para peneliti.

Penelitian Abdullah Aly (2011, p.331) tentang pendidikan multikultural di pesantren (telaah terhadap kurikulum ponpes Assalam Surakarta) menghasilkan salah satu temuan bahwa proses kegiatan evaluasi kurikulum memuat nilai-nilai multikultural terutama nilai demokrasi. Dari sisi lain, ditegaskan bahwa evaluasi kurikulum menemukan nilai-nilai antimultikultural yang berupa nilai konflik, hegemoni, dan dominasi diantara para santri.

Penelitian Dody S. Truna (2010, p.280) tentang Pendidikan Agama Islam berwawasan multikulturalisme menyimpulkan bahwa para penulis buku ajar Pendidikan Agama Islam di perguruan tinggi memiliki kecenderungan dan preferensi masing-masing dalam memilih tema-tema yang dibahas dalam buku ajar yang ditulisnya untuk pegangan mahasiswa. Secara keseluruhan tema-tema yang dikaji dalam buku ajar Pendidikan Agama Islam diperguruan tinggi umum adalah tema-tema agama Islam yang ada hubungannya dengan isu-isu pluralisme agama dan multikulturalisme yang dapat dikelompokan 
menjadi sebelas tema pokok yaitu: kedudukan agama Islam, hukum Islam dan penerapanya, pluralisme agama, toleransi, dan batas-batas toleransi, interaksi antar pemeluk agama, konsep jihad, konsep kesetaraan gender, konsep demokrasi, HAM dan batas-batasanya, serta kepemimpinan dalam Islam.

Tonda (2009, p.35) dalam risetnya Upsetting the Apple Cart:Issues of Diversity in Preservice Teacher Education, meneliti program studi untuk mempersiapkan guru dengan basis pengetahuan dan pemahaman yang diperlukan untuk mengajar di perkotaan yang sangat beragam ketika menghadapi kelas dan faktor-faktor yang perlu dipertimbangkan oleh calon guru. Guru harus memiliki bekal pengetahuan dan pemahaman tentang keragaman terhadap individu yang sangat berbeda dari dirinya sendiri karena akan dapat membentuk sikap siswa terhadap pendidikan multikultural. Calon guru dituntut untuk melihat bahwa identitas pribadinya memiliki orientasi kultur yang membentuk caranya berpikir tentang nilai-nilai, keyakinan, gaya komunikasi, perspektif sejarah, seni, musik, keluarga, ritual, ritus-ritus peralihan, dan kegiatan kelompok sosial lainnya.

Interaksi yang intensif antara guru dengan beragam kultur siswa menjadi faktor dominan dalam pembentukan sikap siswa terhadap implementasi pendidikan multikultural. Penelitian Laduke (2009, p.343) tentang Resistance and Renegotiation: Preservice Teacher Interactions with and Reactions to Multicultural Education Course Content, mengungkapkan interaksi antara guru dan siswa dalam pendidikan multikultural. Melalui pendidikan multikultural, guru dan siswa memiliki kesempatan untuk mendapatkan wawasan tentang realitas kerja sama yang dapat menyebabkan mereka menegosiasikan kembali identitas baru dan realitas yang mencakup warna dan kultur baik di dalam kelas maupun di luar kelas. Program pendidikan guru dalam melakukan reformasi untuk menyusun kerangka konsep multikulturalisme menjadi dasar dan metode pembelajaran pendidikan multikultural.

Wong (2008, p.126) dalam risetnya Transactions, Transformation, and Transcendence: Multicultural Service-learning Experience of Preservice Teachers mengungkap keragaman atau pendidikan multikultural. Fokusnya adalah humanisasi dan tidak tenden- sius terhadap ras sendiri atau identitas etnis. Hal ini terealisasi jika sebagian besar guru (lebih dari $80 \%$ ) dapat mempertimbangkan dan memahami identitas rasial mereka sendiri, khususnya dalam konteks multikultural, yang akan diperlukan sebelum mencoba untuk memahami individu yang berbeda dari diri sendiri. Basis pendidikan multikultural mengarah pada penghargaan dimensi perbedaan yang dimiliki oleh orang lain. Sebagai aspek utama pelaksana praksis pendidikan multikultural, guru juga memberikan penghargaan yang tinggi terhadap perbedaan yang ada. Undang-undang multikulturalisme di Kanada menyatakan dalam mukadimahnya bahwa Kanada berkomitmen untuk menerapkan kebijakan multikulturalisme yang dirancang untuk melestarikan dan meningkatkan warisan multikultural dalam mencapai kesetaraan dalam masyarakat. Undang-undang di Kanada menegaskan bahwa multikulturalisme memberikan nilai sumber daya dalam membentuk masa depan Kanada, tetapi gagal untuk menunjukkan harmonisasi keragaman nasional.

\section{METODE PENELITIAN}

Penelitian ini termasuk jenis penelitian kualitatif-naturalistik. Penelitian ini dimaksudkan untuk meneliti fenomena sosial yang terjadi di MA MINAT Cilacap terkait dengan Pendidikan Agama Islam ditinjau dari perspektif multikultural yaitu tentang makna multikultural menurut guru Pendidikan Agama Islam. Fenomena tesebut dideskripsikan berdasarkan penjelasan subjek penelitian. Data yang diambil lebih bersifat natural yang menggambarkan pendidikan multikultural yang dilakukakan oleh guru Pendidikan Agama Islam di MA MINAT Cilacap.

Penelitian dilakukan di MA MINAT Cilacap. Penelitian intensif di lapangan dilakukan Januari 2012-September 2013. Penelitian pendahuluan sudah dimulai sejak September 2010. Subjek penelitian dipilih dari para praktisi pendidikan di MA MINAT Cilacap yaitu Mu'arofudin,SH sebagai kepala MA MINAT Cilacap, wakil Kepala Madrasah bidang kurikulum, wakil kepala Madrasah bidang kesiswaan, wakil kepala Madrasah bidang Sarpras, guru Pendidikan Agama Islam yang terdiri guru mata pelajaran Al qur'an Hadis, Akidah akhlak, Fiqih dan Sejarah Kebudayaan Islam. 
Analisis data dilakukan dalam bentuk interaktif. Untuk memudahkan analisis data, digunakan teknik interaktif model Miles dan Huberman (1984, pp.21-23), adapun langkahlangkahnya sebagai berikut: (1) pengumpulan data; (2) reduksi data; (3) penyajian data; (4) penyimpulan.

\section{HASIL PENELITIAN DAN PEMBAHASAN}

\section{Makna multikultural menurut guru Pendidikan Agama Islam}

Semakin berkembangnya peradaban Islam dan semakin kompleks di antara aliranaliran pemahaman dalam memaknai Islam, dibutuhkan pemahaman makna yang memiliki wacana multikultural lebih luas. Dimensi-dimensi multikultural membawa pemahaman demokratis terhadap kemajemukan dalam penafsiran teks agama. Kehidupan multikultural menjadi sangat mungkin terjadi sejalan dengan lajunya peradaban maupun pertumbuhan ideologi intern agama Islam. Implikasi lanjut juga memungkinkan konflik antarumat beragama maupun antarmazhab, dalam hal ini pemahaman atas multikultural menjadi urgen untuk dimiliki oleh berbagai elemen yang ada dalam masyarakat. Pendidikan menjadi bagian yang sangat urgen dalam membentuk pemahaman multikultural. Berdasarkan kajian data, maka pemaknaan multikultural di MA MINAT Cilacap menurut guru dapat dipetakan menjadi beberapa varian yaitu: 1) makna persamaan hak 2) makna persaudaraan, 3) dan makna toleransi

\section{Persamaan Hak}

Persamaan hak merupakan salah satu pilar dalam pendidikan multikultural. Implementasi pendidikan multikultural menghilangkan deskriminasi di antara berbagai kultur siswa sehingga akan terjadi persamaan hak di antara siswa dari berbagai kultur yang berbeda. Persamaan hak akan meminimalisasi konflik di antara kultur siswa yang berbeda. Siswa MA MINAT Cilacap yang berasal dari berbagai daerah perlu penanaman sikap persamaan hak.

Persamaan hak juga dikembangkan dalam mensikapi keragaman madzhab yang beragam di dalam Islam. Perbedaan dalam berbagai pemahaman terhadap teks Alquran maupun hadis berimplikasi pada keragaman dalam amalan ibadah ghairu mahdlah ataupun furu'iyah (cabang, bukan pokok). Namun demikian, hal tersebut juga berpotensi menjadikan konflik antarumat Islam, sehingga diperlukan pemaknaan yang benar dalam persamaan hak (Mas'ud, 2004: 19). Adapun makna persamaan hak menurut guru MA MINAT Cilacap adalah sebagai berikut:

hak merupakan kewajiban bagi individu yang tidak boleh diabaikan, maka seseorang bukan saja menahan diri dari menyentuh/merampas hakhak asasi ini melainkan mempunyai kewajiban memberikan dan menjamin hak-hak ini. Maka persamaan hak dalam hal ini berdasarkan dalil diatas adalah memberikan kebebasan kepada mereka untuk mengerjakan amalanya serta menjauhkan sikap yang memberi kesan merendahkan mereka atas amalanya tersebut, sehingga mereka tetap merasa terjaga kehormatnya. (wawancara dengan Mnr guru Fiqih, 12-32014).

Makna persamaan hak menurut guru fiqih seperti diungkapkan di atas penghormatan terhadap hak-hak asasi namun lebih mengarah pada penjaminan hak dan kebebasan dalam perbedaan. Penghargaan hak terhadap amalan-amalan yang berbeda-beda tiap aliran mazhab. Kesadaran dalam memahami perbedaan terhadap keragaman dalam pemahaman dan aliran mahzab yang berbeda didasari pada penafsiran yang lebih luas terhadap ayat-ayat Alquran. Kesadaran terhadap perbedaan adalah seuatu keniscayaan yang sudah menjadi sunnatullah terjadi, sedangkan dalam konteks pembelajaran banyak materi Pendidikan Agama Islam terkait dengan pembentukan kesadaran tersebut. Hal ini memberikan dampak yang lebih luas terhadap guru ketika memaknai perbedaan yang terjadi didalam relasi kemanusiaan. Selanjutnya ditegaskan:

Setiap golongan memiliki kedudukan yang sama dengan yang lainya. Tidak boleh satu golongan menghalangi golongan yang lain guna mendapatkan haknya, hak untuk melaksanakan amalan yang menjadi keyakinan sesuai dengan dasar pijakan mereka. Selama amalan itu tidak menyimpang dari pondasi dasar yaitu Alquran dan 
hadis (wawancara dengan Mjd, 17-32014).

Pemahaman dalam memaknai persamaan hak membawa konsekuensi yaitu ketika memahami perbedaan di antara golongan masyarakat termasuk perbedaan dalam ijtihad masing-masing aliran mazhab yang berbeda. Pemaknaan tersebut akan membawa harmonisasi dalam kehidupan mutlitafsir dengan berbagai macam ibadah ghairu mahdlah (ibadah selain amalan ibadah pokok).

Sebagai umat Islam kami selalu berpandangan bahwa seluruh umat Islam itu saudara. Umat Islam itu bagai satu tubuh di mana anggota lainya saling melengkapi. Kalau salah satu sakit yang lainya pun ikut merasakan begitu pun sebaliknya. Jadi semua umat Islam punya hak yang sama, hak untuk saling tegur sapa, saling mengingatkan, saling menghormat, dan yang pokok adalah menghargai pendapat orang lain. Apalagi kalau itu hasil ijtihad yang digali maka harus dihargai. Prinsipnya kita harus bisa memahami makna satu tubuh. Maka kalau ada yang sakit harus dirawat betul agar sembuh bukan malah dihindari dan benci. Contohnya di MA MINAT ada salah seorang guru yang agak berbeda faham keagamaanya, namun ternyata tetap akrab seperti tak ada jarak. Kalau beliau belum mau berterus terang untuk berbicara mengenai ajaranya, itu hak dia. Mungkin suatu saat mau terbuka (wawancara dengan Msy, 10-3-2014).

Persamaan hak dimaknai lebih luas dalam kebebasan mengikuti aliran-aliran mazhab yang berkembang di masyarakat. Semua orang memiliki persamaan hak termasuk dalam pelaksanaan amalan agama. Kesadaran tentang adanya persamaan hak termasuk dalam menghargai perbedaan. Diantara guru menegaskan:

Setiap individu mempunyai pilihan dan pilihan tersebut kadang tidak sama dalam artian berbeda-beda. Perbedaan menjadi rahmat bagi manusia. Meskipun kita berbeda tetapi hak tetap sama. Dalam kegiatan kita sebagai pendidik ketika dalam mengajar dan melihat adanya perkembangan dari siswa karena berangkat dari latar belakang keluarga yang mereka yakini/amalkan maka kita harus memperlakukan sama dengan siswa yang lain, karena itu adalah hak. Persamaan hak dalam perlakuan belajar itu adalah keharusan. Kecuali ada siswa yang kurang mampu dalam segi belajar dan kepercayaan diri maka perlu ada pendekatan khusus (wawancara dengan Mph, 17-3-2014).

Persamaan hak yang diberikan oleh guru termasuk dalam mengahadapi perbedaan yang terjadi dalam diri siswa. Kultur siswa yang berbeda-beda membawa konsekuensi dalam ragam pembelajaran yang dapat mengakomodasi kepentingan siswa dalam berbagai daerah.

Pemaknaan persamaan hak dalam Islam juga termasuk hak kebebasan dalam mengungkapkan pendapat termasuk hak dalam muamalah maupun siyasah (politik), termasuk penghargaan terhadap berbagai ras yang ada di Indonesia.

Persamaan hak di dalam Islam seperti hak dalam berbicara dan kemasyarakatan. Sebetulnya ada kesamaan antara agama-agama, muamalah dan siyasah (politik) memiliki kesamaan dengan agama lain, cuma..ubudiahnya (tata cara yang mengatur hubungan manusia dengan Tuhan) yang tidak sama. Siyasah (politik) Islam sangat memegang keadilan dan tidak memandang perbedaan ras (wawancara dengan K.Msl, 9 Oktober 2012).

\section{Makna Persaudaraan}

Persaudaraan oleh guru MA MINAT Cilacap disandarkan pada pemahaman bahwa persaudaraan adalah sebuah keniscayaan yang sudah digariskan dalam Alquran sehingga menjalin persaudaraan adalah suatu keharusan. Persaudaraan tidak sebatas hanya pada satu aliran mazhab saja, namun menghargai berbagai perbedaan yang terjadi dalam masyarakat. Guru yang lain mengatakan:

Tali persaudaraan kita adalah iman bukan amalan, Oleh sebab itu sekalipun amalan kita berbeda-beda namun masih dalam satu wadah iman maka 
kita harus selalu membangun kebersamaan dan keharmonisan serta terus menumbuhkan kesadaran bahwa kita semua adalah bersaudara seiman walaupun bukan seamalan (wawancara dengan Mnr, 12-3-2014)

Persaudaraan juga merupakan sunnatullah yang telah ditegaskan bahwa semua orang mukmin adalah bersaudara, sehingga dasar keimanan dan tauhid yang sama menjadi dasar dalam menjalin persaudaraan di antara umat Islam. Persaudaraan tidak tersekat hanya karena beda ragam ibadah dalam Islam. Terkait dengan ini dinyatakan:

Sebagaimana ditegaskan dalam surat Al Hujurat ayat 10 bahwa orangorang mukmin adalah bersaudara, dalam ayat tersebut kata saudara menggunkan kata ikhwah bukan ikhwan, terdapat perbedaan arti meskipun bentuk jama' dari mufrad akhun. Kata ikhwah menunjukan arti saudara sekandung, sedangkan kata ikhwan berarti teman sejawat. Al Quran menganggap persaudaraan dalam satu agama bagaikan persaudaraan dalam satu nasab. Oleh karena itu, sesama mukmin harus mempunyai jiwa persaudaraan yang kukuh. Persaudaraan ini dilatar belakangi karena persamaan keimanan kepada Allah dan Rosulullah (wawancara dengan Mjd, 18-32014).

Sejalan dengan pendapat Msy bahwa persaudaraan yang kuat di dalam Islam adalah didasarkan pada persamaan iman dan akidah, walaupun ragam cara beribadahnya beraneka warna. Persamaan keimanan mengikat persaudaraan yang kokoh. Dengan demikian, persamaan akidah membingkai persaudaraan sesama muslim. Selanjutnya dinyatakan,

Persaudaraan sesama muslim adalah persaudaraan atas dasar seiman, samasama iman kepada Allah dan Iman kepada rosulnya yang terakhir (Nabi Muhammad), terlepas dari cara praktik ibadah yang berbeda-beda. Jika mereka keliru sudah sewajarnya kita mengingatkan saudara kita (wawancara dengan Msy, 11-3-2014).

Persaudaraan sesama muslim merupakan sebuah keharusan dan perbedaan merupa- kan rahmat walaupun di dalam Islam banyak perbedaan cara beribadah yang beragam sesuai dengan pemahaman tafsir masing-masing dan kajian fiqih tertentu. Keragaman dalam amalan fiqih merupakan rahmat yang diberikan Allah Swt. Dinyatakan juga:

Islam juga mengatur tentang hak Jar (tetangga). Hak bertetangga sebenarnya diatur dalam Islam jadi tiga: hak tetangga, saudara, dan seagama Islam, hak tetangga yang seagama, dan hak tetangga yang tidak seagama. Hakhak itu harus diberikan ketika tetangga kita membutuhkan dan hak tetangga yang beda agama jadi metode dakwah yang bijaksana. Kalau ukhuwwah basyariah itu yang mengatur hubungan dengan sesama manusia, karena memiliki hak yang sama sebagai bani Adam. Ada yang lain lagi tentang ukhuwwah wathaniyah itu untuk persaudaraan se-wilayah tanah air entah apa pun agamanya karena manusia di hadapan Tuhan sangat dimuliakan (wawancara dengan $\mathrm{K}$. Msl, 9 Oktober 2012).

Hal di atas merupakan bagian dari memahami makna persaudaraan yang dikembangkan di MA MINAT Cilacap. Internalisasi makna persaudaraan menjadi melembaga dan tertanam dalam diri anak sehingga pemaknaan persaudaraan di MA MINAT Cilacap tidak hanya dibatasi satu keyakinan agama tetapi juga karena aspek-aspek kemanusiaan yang lain. Bahkan pemaknaan persaudaraan di MA MINAT Cilacap juga didukung di tingkat yayasan dengan digalakkan suhbah dan qurbah (persaudaraan dan kekeluargaan) yaitu persaudaraan di luar keluarga dan persaudaraan antar keluarga (kekeluargaan). Artinya, MA MINAT Cilacap memaknai persaudaran lebih luas tidak hanya sebatas pada kekeluargaan. Suhbah merupakan persaudaraan antara sesama manusia sedangkan qurbah merupakan bentuk persaudaraan yang diikat oleh tali kekeluargaan.

\section{Makna Toleransi}

Toleransi menjadi sendi dalam kehidupan multikultural. Pemaknaan toleransi menurut guru pendidikan agama Islam MA MINAT Cilacap yang sebagian sebagai pengasuh pesantren lebih memiliki makna yang terbuka 
terhadap beberapa perbedaan yang terjadi di dalam masyarakat. Aspek-aspek penghargaan terhadap keragaman kehidupan multikultural dari sisi kemajemukan amaliyah dan mazhab dalam Islam disikapi dengan sikap toleransi. Artinya toleransi dengan pemahaman yang tidak terlalu fanatik dan tidak menyalahkan perbedaan di antara ajaran aliran mazhab dalam Islam.

Implikasinya dakwah dalam Islam dimaknai tidak melakukan pemaksaan kebenaran mazhab tertentu terhadap mazhab lainya. Dengan demikian, terdapat anjuran untuk berkerja sama dalam kemajemukan pemahaman dalam Islam. Islam tidak menutup kemungkinan untuk menjalin kerja sama dalam hubungan sosial. Implementasi toleransi telah dilakukan oleh MA MINAT Cilacap dan ponpes Al Ihya Ulumudin. Terkait dengan hal ini dikemukakan oleg seorang guru:

Satu pemahaman toleransi adalah apabila sekarang banyak gerakan-gerakan kekerasan yang mengatasnamakan agama dengan nama salafi, yang dulu makna salafi memiliki konotasi baik dan biasanya digunakan oleh orang-orang NU (nahdaltul ulama). Dakwah tidak boleh memaksakan pemahaman aliran tertentu atas aliran yang lain di dalam Islam dan kita tidak boleh mengkafirkan orang-orang di luar Islam tetap kita santun dan kita tetap bisa mengajak bekerjasama. Bahkan dulu di MA MINAT Cilacap dan Pesantren sini (Al Ihya Ulumudin) pernah ada pertunjukan barong sai yang ini artinya kita juga telah bekerja sama dengan non Islam (Cina) (wawancara dengan kepala madrasah 11 Oktober 2012).

Toleransi dimaknai oleh guru MA MINAT Cilacap adalah memberikan penghargaan terhadap semua perbedaan yang ada di dalam intern umat Islam serta memberikan kesempatan untuk menjalankan amalan sesuai dengan pemahaman mazhab tertentu. Dikatakan:

Toleransi dalam hal ini adalah sikap terbuka dan mau menjalani adanya berbagai macam perbedaan amalanamalan selain amalan kita serta memberikan kebebasan untuk menjalankan amalan masing-masing. Hal ini lebih dikenal dengan istilah tasamuh dalam Islam. Tasamuh bukan barang baru dalam Islam karena Rasulullah melaksanakan hal itu terhadap para sahabatnya yang berbeda dalam menjalankan ajaranya. Contohnya adalah pelaksanaan sholat witir yang dilaksanakan oleh Abu Bakar dan Umar. Abu Bakar melakasanakan shalat witir sebelum tidur sedang Umar tengah malam setelah tidur. Hal ini diadukan pada Rasulullah dan Rasulullah menjawab semua baik (wawancara dengan Mnr, 12 Maret 2014).

Makna toleransi menurut guru MA MINAT Cilacap juga disandarkan pada pemahaman ayat bahwa orang Islam dalam bentuk apapun aliranya adalah menjadi saudara. Dengan demikian, toleransi termasuk memberikan penghormatan atas kemajemukan pemikiran yang terjadi di dalam masyarakat.

Toleransi memberikan kebebasan dalam memahami hasil ijtihad yang beragam di dalam Islam. Ragam amalan ibadah dalam Islam sangat bergantung pada imam mazhab yang selanjutnya menghasilkan istinbath hukum yang majemuk. Sebatas tidak melanggar hukum mahdlah maka masih dibenarkan dan toleransi menurut guru MA MINAT Cilacap dalam rangka memberikan kebebasan terhadap ritual ibadah yang berbeda. Terkait dengan tasamuh dinyatakan:

Tasamuh terhadap pemeluk agama lain dengan cara membiarkan mereka yang penting tidak mengganggu dan tetap kita pada keyakinan sendiri. Ya...diam bukan berarti menyetujui terhadap agama mereka dan bukan berarti ijma' sukuti (diam bukan berarti menyetujui). Orang di luar Islam tidak boleh dimusuhi asal mereka tidak memusuhi kita, kecuali kafir harbi (kafir yang memusuhi Islam). Tasamuh (toleransi) membuat suasana kondusif dalam masyarakat. Prinsipnya kita jangan memusuhi mereka karena akan terjadi sebaliknya. Justru dengan tasamuh (toleransi) akan mengangkat agama Islam. Sebagai contoh dapat mengambil dari dakwah Nabi di Madinah yang waktu itu menghadapi berbagai macam golongan masyarakat. Setelah Nabi berhasil 
di Madinah barulah beliau mengirimkan utusan untuk dakwah di Mekkah (wawancara dengan K.Msl, 9 Oktober 2012).

Hal ini didukung juga konsep tawazun yang dilakukan oleh yayasan YaBakii. Tawazun yang diharapkan oleh pendiri YaBakii (MA MINAT Cilacap salah satu lembaga pendidikan di bawah YaBakii) mengarahkan sikap pada keseimbangan antara hubungan sesama manusia dan dengan sang khalik. Dinyatakan

Semua yang dilakukan di yayasan tersebut adalah seimbang antara aspek dunia dan akhirat sehingga perlu mendukung perlakuan adil karena itu justru akan dihormati oleh agama lain juga dan bagian dari dakwah. Islam termasuk orang-orang yang menggunakan dakwah dengan tiga cara yaitu mauidzah, mujadalah, dan hikmah. Dakwah dengan mauidzah dengan cara ngomongi (menasehati) atau membujuk, tapi kalau mujadalah dengan dialog dengan cara hikmah. Metode ini sama seperti para wali menaklukan raja kafir(wawancara dengan K.Msl 9 Oktober 2012).

Dakwah wajib dilakukan tetapi jika orang lain supaya ikut dengan itu yang tidak wajib. Sedangkan pengertian jihad (sekarang) menurut orang pesantren yaitu apa saja yang diperjalankan dalam kebenaran itu jihad, termasuk peningkatan ekonomi itu juga jihad. Jihad jaman nabi memang dilakukan dengan perang karena Islam hadir dalam masyarakat yang memusuhi Islam.

\section{Pembahasan}

Makna multikultural menurut guru Pendidikan Agama Islam MA MINAT Cilacap dapat dipilah menjadi beberapa bagian, yaitu: 1) makna persamaan hak, 2) makna persaudaraan, dan 3) makna toleransi

\section{Makna Persamaan Hak}

Kultur siswa MA MINAT Cilacap sangat beragam berasal dari berbagai daerah dari luar Jawa. Kondisi tersebut selain sebagai potensi sekaligus juga dapat menjadi faktor yang rentan terhadap konflik. Berbagai daerah asal siswa membawa kompetensi kultural melalui sosialisasi siswa dari berbagai daerah yang membawa budaya yang beragam dengan demikian siswa terbiasa hidup dalam kemajemukan (Ekstrand, 1994:21). Namun, kondisi tersebut juga dapat memicu pertikaian di antara siswa karena perbedaan budaya. Sikap yang ditanamkan guru dalam Pendidikan Agama Islam dengan berbasis pendidikan multikultural adalah menanamkan sikap kepada siswa tentang persamaan hak dan menghilangkan sekat-sekat kedaerahan. Diskriminasi terhadap satu budaya dan budaya yang lain dalam pendidikan multikultural di MA MINAT Cilacap adalah satu sikap yang harus dihindari. Persaman hak yang dikembangkan guru Pendidikan Agama Islam MA MINAT Cilacap merupakan pilar dalam pendidikan multikultural.

Secara ringkas makna persamaan hak menurut guru pendidikan agama Islam MA MINAT Cilacap adalah:

\section{Persamaan dalam amaliyah dan mazhab}

Keragaman dalam bidang amalan beribadah dan keyakinan pemahaman terhadap aliran mazhab merupakan bagian yang menjadi persamaan hak di dalam Islam. Potensi konflik dalam perbedaan amaliyah Islam sering memicu terjadinya perpecahan. Namun perbedaan yang ada dimaknai oleh guru pendidikan agama Islam sebagai bentuk persamaan hak dalam melakukan amaliyah yang harus dihormati karena setiap umat Islam memiliki hak yang sama dalam melakukan interpretasi atas teks Alquran sehingga menjadi keniscayaan adanya perbedaan dalam hal beribadah. Hal tersebut menjadi bagian dalam persamaan hak dalam Islam.

\section{Persamaan dalam Ijtihad}

Semua umat Islam memiliki kekebasan dalam berijtihad. Kebenaran dalam berijtihad dalam Islam merupakan kekebasan yang dimiliki oleh umat Islam. Bahkan ketika salah dalam berijtihad juga mendapatkan pengharagaan atas olah pikir yang telah dilakukan.

Keragaman yang terjadi dalam melakukan ijtihad merupakan persamaan hak di dalam Islam. Guru agama Islam MA MINAT Cilacap memaknai persamaan hak juga memberikan persamaan dalam melakukan ijtihad, 
walaupun hasil dari perbedaan ijtihad akan membawa perbedaan dalam praktik ibadah.

Makna persaudaraan

Persatuan bagi guru MA MINAT Cilacap merupakan sendi dalam membangun relasi sosial yang dikembangkan secara kelembagaan. MA MINAT Cilacap yang bernaung dalam yayasan YaBakii Cilacap tidak lepas dari ide-ide dasar yang dikembangkan yayasan. Suhbah dan qurbah (persaudaraan dan kekeluargaan) merupakan moto yang dikembangkan yayasan dalam rangka memberikan inspirasi bagi warga Madrasah. Secara kelembagaan MA MINAT Cilacap membuka diri untuk membangun persaudaraan dan persahabatan meskipun dengan orang-orang di luar Islam. Hal ini sesuai dengan pilar pendidikan multikultural yaitu menghilangkan prejudice yaitu menghilangkan sekat kecurigaan terhadap komunitas lain (Banks, 2007, p. 90).

Makna persaudaraan menurut guru pendidikan agama Islam MA MINAT Cilacap dapat dibedakan menjadi dua:

\section{Persaudaraan suhbah (persaudaraan sesama manusia)}

Persaudaraan dimaknai oleh guru pendidikan Agama Islam adalah tidak hanya sebatas persaudaran dalam satu keturunan. Namun persaudaraan juga tidak hanya terbatas hanya dalam lingkup persaudaraan dalam ikatan keturunan. Relasi yang lebih jauh dalam berinteraksi sosial tanpa batas ikatan persaudaraan dan satu keturunan sehingga membentuk hubungan sosial yang dapat melintasi batas ras, bahasa, dan kultur yang berbeda. Dengan demikian, nilai-nilai multikultural diinternalisasikan dalam pendidikan agama Islam.

\section{Persaudaraan Qurbah (persaudaaran dalam ikatan keluarga)}

Selain membangun relasi kemanusiaan secara luas, persaudaraan juga dimaknai dengan qurbah yaitu menjalin persaudaraan karena didasarkan dengan satu keturunan. Dengan demikian jalinan persaudaraan menjadi komprehensif yaitu menjalin pola relasi kemanusiaan dan tetap menjalin persaudaraan dengan dalam ikatan persaudaraan.
Persaudaraan qurbah, menurut guru pendidikan agama Islam, adalah persaudaraan yang wajib dilakukan karena persaudaraan dalam satu keturunan merupakan menjadi pengikat persatuan antarkeluarga dalam Islam dan sekaligus memperkokoh persaudaraan sesama muslim.

\section{Makna Toleransi}

Toleransi bagi guru MA MINAT Cilacap dalam era multikultural dimaknai sebagai sikap menghormati atas semua perbedaan dalam beragama dan kemajemukan dalam kepercayaan. Menurut guru Pendidikan Agama Islam MA MINAT Cilacap tidak membenarkan adanya sikap fanatik yang berlebih-lebihan. Hal tersebut sesuai dengan ajaran Islam yang sangat memberikan kebebasan dalam memeluk agama. Ajaran pendidikan multikultral juga memberikan peluang toleransi dan memberikan penghargaan tinggi terhadap nilai-nilai perbedaan yang berkembang dalam masyarakat (Banks, 2005: 46). Dengan demikian, membangun relasi sosial terhadap seluruh lapisan masyarakat adalah sangat dijunjung tinggi oleh personel MA MINAT Cilacap.

Toleransi beragama oleh guru Pendidikan Agama Islam MA MINAT Cilacap dengan memadang dakwah dan jihad tidak dimaknai sempit bahwa harus selalu berkonotasi dengan perang dan menegakakan negara Islam dengan ditempuh melalui kekerasan. Hal itu melanggar dengan hak-hak kemanusiaan dan hak kebebasan beragama. Jihad dimaknai oleh guru Pendidikan Agama Islam, MA MINAT Cilacap mencari keridoan Allah. Konsekuensinya jihad merupakan bagian dan jalan untuk mencari kegiatan-kegiatan positif yang menjadi usaha untuk melestarikan perdamain bagi umat banyak. Jihad oleh guru Pendidikan Agama Islam MA MINAT Cilacap bukan berarti kebebasan untuk melakukan penekanan terhadap agama lain, sehingga dalam pendidikan dimaknai sebagai ikhtiar dalam membantu anak didik melalui proses pendidikan.

Adapun makna toleransi dapat dibedakan sebagai berikut.

\section{Tasamuh}

Pendidikan multikultural sangat menjunjung toleransi dan sikap demokratis seba- 
gai bentuk penghargaan terhadap perbedaan cara pandang, ide maupun kemajemukan budaya (Burnet, 2007, p.12). Pendidikan multikultural merupakan pendidikan antirasial yang memandang toleransi antara semua lapisan masyarakat. Guru Pendidikan Agama Islam MA MINAT Cilacap memaknai toleransi dengan sikap tasamuh.

Tasamuh diimplementasikan dalam Pendidikan Agama Islam yang humanis dan demokratis. Sikap toleransi membuka jalan damai dan kultur akademis yang kondusif, sehingga dengan demikian akan terbentuk pemberdayaan siswa serta peningkatan mutu pendidikan Islam. Penanaman toleransi menjadi bagian dalam pilar pendidikan multikultural. Tasamuh dalam proses pembelajaran dapat dilakukan lebih terbuka dalam perbedaan termasuk keragaman agama. Makna humanis dan demokratis termasuk dalam melakukan dakwah. Tasamuh dalam Islam berimplikasi pada dakwah sebagai bentuk ikhtiar menyampaikan kebenaran Islam, sehingga anggapan tentang mendirikan negara Islam menjadi bertentangan nilai-nilai humanis dan demokratis.

\section{Tawazun (keseimbangan hubungan kemanusiaan)}

Guru MA MINAT Cilacap memaknai toleransi adalah sebagai bentuk tawazun yaitu mengedepankan kesimbangan dalam hubungan relasi kemanusiaan. Artinya, dalam pola pergaulan tidak membatasi pada kelompok tertentu, namun pergaulan yang dikembangkan tanpa tersekat dengan adannya perbedaan budaya, ras, bahasa dan perbedaan agama. $T a-$ wazun juga membentuk harmonisasi hubungan dan perdamaian dalam masyarakat. Dengan demikian pemaknaan toleransi yang benar akan membawa pada nilai-nilai multikultural dalam diri anak didik.

\section{SIMPULAN DAN SARAN}

\section{Simpulan}

Berdasarkan temuan hasil penelitian dan analisis data yang telah dilakukan terhadap kajian multikultural pada Pendidikan Agama Islam di MA MINAT Cilacap maka dapat diperoleh simpulan sebagai berikut:

Makna multikultural menurut guru Pendidikan Agama Islam MA MINAT Cila- cap tidak lepas dari pengaruh yang dikembangkan Institusi. MA MINAT Cilacap mengembangkan konsep tawazun dan mengedepankan tasamuh membawa konsep yang baik terhadap pendidikan multikultural. Makna multikultural antara lain tentang persamaan hak yaitu harus diberikan lembaga pendidikan sebagai institusi sebagai tempat untuk melakukan pemberdayaan siswa. Persamaan hak menjadi pondasi dasar dalam meminimalisasi konflik yang berkembang dalam masyarakat. Pemberdayaan siswa MA MINAT Cilacap pada sikap persamaan hak memberikan nilai positif pada pembentukan perilaku yang dapat menerima perbedaan. Makna persamaan hak adalah jika tidak ada perbedaan hak antara siswa yang berasal dari berbagai daerah maka perolehan hak antarsiswa menjadi setara.

Sikap guru MA MINAT Cilacap terbuka terhadap keberagaman bahasa dan budaya, serta menghargai karakter siswa dari beragam daerah. Sikap tersebut didukung pemaknaan multikultural menurut guru dan siswa tentang makna multikultural. Sikap siswa telah memiliki pemahaman dan kompetensi kultural. Sikap siswa memberi makna adil yaitu merupakan perlakuan yang sama antarras. Sedangkan persaman hak adalah penghargaan atas keragaman bahasa yang dimiliki oleh siswa.

\section{Saran}

Nilai-nilai multikultural yang telah dikembangkan di MA MINAT Cilacap dapat dikembangkan menjadi satu kebijakan yang ditetapkan oleh yayasan Ya Bakki terhadap implementasi pendidikan multikultural. Diperlukan perangkat pendukung dan regulasi yang mengatur bagi implementasi pendidikan multikultural di MA MINAT Cilacap.

\section{DAFTAR PUSTAKA}

Aly, A.(2011). Pendidikan islam multikultural di pesantren telaah terhadap kurikulum pondok pesantren modern islam assalam surakarta. Yogyakarta: Pustaka Pelajar.

Alquran Al Karim.

Azra, A. (2002). Paradigma baru pendidikan nasional: rekonstruksi dan demokratisasi. Jakarta: Penerbit Buku Kompas 
Banks, J.A. (2005). Multicultural education: issues and perspectives, fifth edition. America: JhonWiley \& Sons, Inc.

Banks, J.A. (2007). Educating citizens in a multicultural society. Second edition, New York: Teacher college press.

Burnet, G.(2007). Varieties of multicultural education: An introduction: New York: Eric Publication.

Ekstrand,L.(1994). Multicultural education. J.Saha (ed). International encyclopedia of the society of education. New York: Pergamon.

Laduke, A.E. (2009). Resistance and renegotiation: preservice teacher interactions with and reactions to multicultural education course content [Versi Elektronik]. Journal of Multicultural Education, 16, 3,343357.

Lynch,J. (1986). Multicultural: Principle and practice. London: Routledge \& Kegan Paul.

Marzuki dkk.(2010). Tipologi perubahan dan model pendidikan multikultural pesantren salaf. http//staff.uny.ac.id, 12 Januari 2014 14:20 WIB.

Mas'ud, A. (2004). Format baru pola pendidikan keagamaan pada masyarakat multikultural dalam perspektif sisdiknas. Dalam Muamar Ramadhan \&
Hardinal (eds), Antologi studi agama dan pendidikan. Semarang: CV Aneka ilmu.

Miles, M.B., Huberman, A.M. (1992). Analisis data kualitatif. Alih Bahasa Rohidi,T.R.Jakarta: UI Press.

Shihab, A. (1999). Islami inklusif, menuju sikap terbuka dalam beragama, Bandung: Mizan.

Tilaar, H.A.R. (2002). Pendidikan, kebudayaan dan masyarakat madani Indonesia: strategi reformasi pendidikan pendidikan nasioanal. Bandung: Rosda Karya.

Tonda (2009: 35) Upsetting the Apple Cart:Issues of Diversity in Preservice Teacher Education

Truna, D.S.(2010). Pendidikan Agama Islam Berwawasan Multikulturalisme: Telaah kritis atas muatan pendidikan multikulturalisme dalam buku ajar pendidikan agama Islam di perguruan tinggi umum di Indonesia: Jakarta: Kemenag RI

Wong, P. (2008). Transactions, transformation and transcendence: multicultural service-learning experience of preservice teachers [Versi Elektronik]. Journal of Multicultural Education, 16, 126139. 